TRAINING THE THEATRE ARTS TEACHER IN NIGERIAN COLLEGES OF EDUCATION: PROBLEMS AND PROSPECTS

*Marcellinus Aondohemba ASEN

Abstract

This article seeks to identify and proffer solutions to the problems confronting the theatre arts teacher training in Nigerian colleges of education. It also advances the prospects of effective theatre arts teacher training in the educational sector and the society at large. In doing these, the researcher adopts the interview, focus group discussion (FGD) and observation methods to collect data. Given that many colleges of education in Nigeria offer theatre arts as a course, the researcher narrows down the scope of the research to Katsina$\mathrm{Ala}$ and Oju Colleges of Education in Benue State. The major finding of the study is that, the theatre arts teacher training programe is confronted with numerous problems which militate against its effective execution, thereby making the aim of the programme to be almost defeated. It argues that the theatre arts teacher occupies a central place in equipping school children with creative and imaginative skills, which are capable of building their lives through the teaching of drama, creative arts and music in primary and post primary school levels. It is in view of this that the study recommends that the government, college management and lecturers of theatre arts in colleges of education should show a high sense of comitment in improving the quality of theatre arts teachers trained at that level of tertiary education.

Keywords: Theatre arts teacher, Nigerian colleges of education, Learning, NCCE, NUC, Theatre arts

Introduction

In all societies of the world, human beings need to develop and grow up properly as individuals. This process is only made possible by education. This is why it is often said that "to educate an individual is to make such an individual useful to himself or herself as well as to the society. In educating an individual both formally and informally,

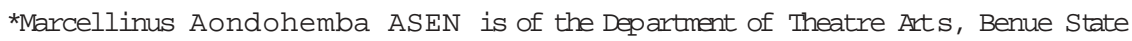
University, Makurdi

Email: asenmarcel@omail.com 
the teacher is at the centre of the process. This means, in all the stages or levels of education, the teacher plays unique roles for leaming to take place. However, a teacher's role may vary among cultures and places ranging from providing instructions in literacy and numeracy, craftsmanship or vocational training, the arts, religion, civics, cormunity roles, or life skills. In formal educational setting, the teacher imparts knowledge and facilitates students' learning in schools or academies.

Teaching in it self is not an easy exercise and as such all ef fats must be put in place to make it result-oriented. This is why many governments of the world operate teachers' colleges, which are generally established to serve and protect the public interest through certifying, governing and enforcing the standards of practice for the teaching profession. Also, there are a variety of bodies designed to instil, preserve and update the knowledge and professional standing of teachers. All these are done in recognition of the key role education plays in society and the place of teachers in driving the process.

In Nigeria, colleges of education and universities offering bachelors degree in education (B.Ed) are saddled with the responsibility of training teachers in all disciplines. Also, regulatory bodies such as the National Cormission for Colleges of Education (NCCE), and National Universities Commission (NUC) are responsible for the laying down of minimum standards for all programmes of teacher education and accrediting their certificates and other academic awards at colleges of education and universities respectively.All these schools and bodies work towards quality assurance and the excellent production of teachers for the educational sector. While the colleges of education produce graduates with the Nigerian certificate in education (NCE) which is the minimum qualification for teaching in the primary and post-primary school levels, university graduates of education in all disciplines hold professional degree certificates, which enable them to teach at all levels of education.

Theatre arts as a discipline has remained one of the basic tools for exploring and expressing human feelings and predicaments. This is because, it is a collaborative art form; rich in history and it speaks to all societies since it mirrors human emotions, morality, and fant asies. Being a fundament al human activity, it involves people working together in order to communicate ideas and explore social issues in response to the various situations affecting them. Hence, it demands discipline and dedication thereby making it both a delight and a challenge. Given this circumstance, the theatre arts is a discipline that cormands respect and there is every need to leam and teach it. This is why it is taught in colleges of education and universities throughout Nigeria. 
The theatre arts teacher education sequence in colleges of education is dedicated to preparing highly qualified artists/teachers to meet the challenges of teaching in the primary and post-primary school levels. As a theatre student teacher, you receive a solid foundation of basic skills in traditional theatre courses such as acting, directing, design, theatre history and dramatic literature, choreography and technical theatre. At the same time, you will follow a course of instruction specifically focused on teaching at the primary and postprimary school levels. The theatre arts department mounted in colleges of education, therefore, enhances the teaching and professional skills of students. This is because, at that level of education, the teaching of theatre arts is done in addition to the general preoccupation of teacher training in the college. This is why these categories of artists are also professional theatre arts teachers.

Unfortunately, the teaching of theatre art s in Nigerian colleges of education has overtime encountered different problems in different places. These problems have hindered the effective teaching and leaming of theatre arts studies, thereby militating against the effective training of theatre teachers in colleges of education. Most of these challenges are administratively inclined, making teaching and learning difficult. If, therefore, the training of theatre teachers who are expected to teach drama, music and creative art courses at the primary and post-primary school levels is faced with problems, all hands must be on deck to sumount these problems in order to have an effective theatre teacher training at colleges of education. Given that there are many colleges of education in Nigeria offering theatre arts as a course and it will be intractable for the researcher to go round them, this study sets out to look at the remote and distant problems confronting theatre teacher training in Katsina-Ala and Oju Colleges of Education in Benue State with a view to suggesting appropriate measures towards overcoming the identified problems.

\section{The Concepts of Teaching and Learning}

Generally, the concept of teaching can be looked at from dif ferent perspectives. It could be seen as the act, practice, occupation, or profession of a teacher. According to Fafunwa, teaching is defined as, "the action of someone who is trying to assist others to reach their fullest potentials in all aspects of development" (28). On the other hand, teaching according to Peters can be, "a way of sharing power or convincing people to value what you value, or explore the world with you or through you" (15). This is an all-encompassing definition and can be analyzed as "sharing", which connotes two people - dividing phenomenon, which in this case, may be knowledge. This presupposes 
that, both the teacher and learner (student) are contributors to the ability of knowing things which Peter refers to as "power". Another point that can be deduced from this definition is "conviction". Here, a teacher's thought or belief is being imparted through persuasion or imposition because the teacher wants to 'sell' his or her values to the learners. This is more or less related to science where teachers and students explore the world through laboratory experiments. This is also applicable to dramatic arts where creativity can be explored by the students through the teacher or by joint efforts of both the teacher and the students. Beck corroborates this postulation by saying that, "in teaching drama, teachers and students are engaged in collective enquiry and exploration" (19).

On the other hand, learning according to Farrants is, "the process where an activity originates or is changed through training procedure (whether in the laboratory or in the natural environment) as distinguished from change by factors not attributed to training" (52). He links learning to a variety of activities such as swiming, dancing, driving a car, reading and writing as well as the more complex process of leaming to adapt to the society. As well, Fafunwa conceptualises learning as the "process by which we acquire and retain attitude, knowledge, understanding, skills and capacity that cannot be attributed to inherited behavioural patterns or physical growth" (32). Furthermore, Peters sees learning as "an activity which is deliberately pursued for the purpose of obtaining information, acquiring greater understanding or improving a skill" (20). These views suggest that learning must be engaged consciously and, therefore, it entails personal ef fort or will-power. It also implies that such an activity could be misused or used properly. When leaming is properly utilized, it enables the learners to discover basic ideals in the study and the leaming materials. This is why Peters advocates for the need to direct learning properly in order to be beneficial. He emphasizes this need by putting forth his concept of "supervised and guided learning" which he describes as:

That plan of school procedure whereby each pupil is so adequately instructed and directed in method of learning and thinking, that is daily done and prepared in a progressive way under condition most favourable to a hygienic, economic and selfreliant career of intellectual endeavour. (25)

This definition presupposes that learning does not seek to just prepare pupils for graduation in colleges or tertiary institutions, but to helps 
them to cope efficiently with problems in this world of intense competition. In such a situation, superior achievement depends on initiating clear thoughts and confidence in one's ability to organise experience for new adjustments. This kind of learning aims at producing an individual who is trained to attack problems and to organise his or her experience into a large controlling concept which will endow him or her to initiate ideas or to serve or work without or little supervision. Derivatively, this suggests leaming as ability, which needs proper direction and is consciously engaged in order to develop one's thinking and initiative. At times, learning can also be something we come about unawares, since the process of learning begins from the birth of a child and continues throughout his/her life time. This is also possible because learning occurs when a sort of observable behavioural change has taken place in the life of such an individual which he or she may not be aware of. Accordingly, teaching can only take place where there is a leamer or else it will be an exercise in futility. The learner must not only be available but favourably disposed to learning what is being taught. Teaching and learning entail a process which can only be achieved through careful and methodological approach.

\section{The Theatre Arts Teacher}

In the context of this study, a theatre arts teacher is one who has acquired a professional educational training in theatre arts in a college of education or university faculty of education. In which case, he/she has the requisite skills of theatre and teaching qualification. As such, the theatre teacher knows how to plan and implement effective theatre instruction and assessment and provide students with learning experiences that enhance their knowledge, skills, and appreciation in theatre art s studies. Also, the theatre teacher underst ands and applies skills for creating, utilizing, and/or performing dramatic material. Furthermore, the theatre teacher must understand and apply skills for producing and directing theatrical productions. He/she must have the knowledge of design and technical theatre as well as different cultures and historical periods. Fundament ally, the theatre art s teacher must understand and apply skills for responding to, analyzing, and evaluating theatre as well as the interrelationship between theatre arts and other disciplines.

Theatre arts teachers assist students in exploring their creativity and building interpersonal skills via classroom activities and theatre productions. They utilize instructional methods to create lesson plans, exercises and other activities to help students in mastering costume and set design, acting and directing, etc. In the primary and postprimary schools, theatre teachers have a responsibility of coordinating 
school children for dramatic and theatrical activities in schools. These could be during end of term/year party, when schools have august visitors or in dramatic club activities. In this way, school children are taught how to carry out a performance, be it a dance, mime, drama, music and the like. Also, they learn art work which can become useful to them even in the future.

In the tertiary or university level, the theatre arts teacher basically teaches theatre arts as a course of study. It becomes easier as the training is focused and emphasis is placed on matching theory with practice. Here, the theatre arts teacher is basically involved in the training of prospective theatre artists who can, on graduation, practice the arts of the theatre. The theatre arts teacher as a matter of fact occupies a central place in the education of school children and students at all levels of the educational process especially in the creative arts. In Nigeria, professional theatre arts teachers are only produced in colleges of education, hence, theatre arts is not housed in the faculty of education in any Nigerian university but in the faculty of arts.

The Prospective Theatre Arts Teacher in Training at Colleges of Education

The success of any theatre arts training programme is dependent on the competence of the lecturers assigned to teach courses and the equipment/facilities available for use. Lecturers teaching theatre arts in colleges of education should receive training and professional development at a high level. They should be credentialed in theatre arts and education. They should have a fair knowledge of the following:

- Performance - acting, stage, TV, film, broadcasting, puppetry, diildren's and youth theatre, musical theatre, mime, movement, voice, and improvisation;

- Production - theory and practice, directing, playwriting, dramatic literature, theatre history, criticism, and dramaturgy;

- Theatre Management - arts management, marketing, public relations, publicity, facility management;

- Technical Design and Construction - costumes, make-up, sets, props, sound, lighting, and multimedia (Amanda Swann 3). This is the only way the lecturers can match theory with practice because theatre is performance and everything that is done in the course of the training is tilted towards bringing out the practical creativity and imagination of prospective theatre teachers and artists on stage or screen. Also, graduates of colleges of education are expected to 
teach at the primary and post-primary school levels. They, therefore, require total training in the arts of the theatre to be able to function properly. Jensen captures it more holistically when he asserts that, "the real driving force behind dramatic arts is what it does for the emotional, physical, and cognitive abilities of the student.." (76). If the prospective theatre teacher in training at college of education is guided by qualified theatre educators, direct study and active participation in theatre will offer him or her unique situations in which he or she will develop and demonstrate his or her cognitive and affective skills, critical modes of thought, cultural values and beliefs, and his or her comprehension of self and others will be better enhanced.

The Content of Theatre Arts Programme in Nigerian Colleges of Education

Generally, theatre art s discipline is divided into three major areas, namely, the managerial/administrative area, the performing area and the technical area. These aspects feature prominently in all theatres be they educational, private or government owned. In teaching all these areas, so many things are put in place. This is why in theatre training many courses are put in place to capture the three major areas of the theatre st ated above. According to Felix Egwuda-Ugbeda, "the theatre arts discipline covers a spectrum of programmes such as history, playwriting, play production, acting, directing, criticism, dramatic literature, constructions, management, administration, dance, cultural studies, tourism, communications, aesthetics, costume, make-up, props, research, children's programes, film arts, public relations, media arts, etc. Each of the above areas is human-oriented as it delves into human existence, philosophy, psychological state, behaviour and human attitude" (498).

In Nigerian colleges of education, theatre arts is not studied as a double major course and on completion of their studies students are issued the Nigerian certificate in education (NCE) in theatre arts. As a result, they have to combine Theatre Ants with another course such as English, French, Christian Religious Studies CRS and the like. This is partly in view of the fact that theatre arts is not offered as a subject in the primary and post-primary school level where these graduates are expected to teach. The curriculum of theatre arts, therefore, is structured in a manner that students offer courses in theatre and any other subject which form their core course as well as courses in education to qualify them to be professional teachers. 
Basically, the curriculum houses the arts of the theatre such as acting, directing, playwriting and dramaturgy, costume and make-up design and technical theatre. Also, courses in theatre management, film production, theatre history, cormunity theatre and children's theatre are all bouilt in the arrioulum. A student can successfully graduate in the Department if he passes a total of thirty-three credit units in theatre arts. Egwuda-Ugbeda further asserts that "theatre arts is an art and a discipline, which focuses on human, human resources and human society (sic). It is a discipline that searches human mind, records human mind and sees that human beings are moulded into perfect beings. In other words, theatre builds a cultivated human being. Theatre arts is a discipline that delves into the society, underst ands the components of society and tries to bring society in line with the dictates of nature" (499). As a result, theatre arts has the propensity of building a robust society .

Methods of Teaching the Prospective Theatre Arts Teacher at Katsina-Ala and Oju Colleges of Education

A teaching method comprises the principles and methods used for instruction to be implemented by teachers to achieve the desired learning in students. These strategies are determined partly by the subject matter to be taught and the nature of the learner. For a particular teaching method to be appropriate and efficient it has to be in relation with the characteristic of the leamer and the type of leaming it is supposed to bring about. This is why Davis cited in Westwood suggests that "the design and selection of teaching methods must take into account not only the nature of the subject matter but also how students leam" (10). At Kat sina-Ala and Oju Colleges of Education, this study has identified three teaching methods, namely, the lecture method, the theatre workshop method and the excursion/field work method.

\section{The Lecture Method}

The lecture method is considered the primary method of teaching theatre arts in the two colleges of education. It is a method in which the lecturer stands before his or her students and delivers a lecture on what he or she has to teach them. This is achieved mainly by the power of speech. It is viewed as the most convenient method of teaching on the side of the lecturer as all he or she needs to do is talk. This method also makes more sense where one has a larger number of students in the classroom. While the lecture method gives the instructor or teacher the opportunity to expose students to unpublished or not readily available materials, the students play a passive role 
which may hinder learning. On the other hand, while this method facilitates large-clas s communication, the lecturer must make constant and conscious efforts to become aware of students' problems and engage the students to give verbal feedback. It could be used to arouse interest in a subject provided the instructor has effective communication skills.

\section{Excursion and Field Work Method}

The excursion/field method is adopted in the teaching of theatre att $\mathrm{s}$ at Kat sina-Ala and Oju Colleges of Education. Basically, excursions and field work aim at offering students the opportunity to apply theoretical knowledge, methods and techniques practically in the field. Although this method is secondary in theatre studies it is beneficial in the sense that the students get knowledge of current research, meet professionals in the labour market, develop observation skills, practice both individual work and team work, experience unfamiliar places, make new discoveries, get new impressions, perspectives and ideas. This is seen in the teaching of community theatre at NCE II.

Community theatre is known with many other nomenclatures such as theatre for development, gorilla theatre, applied theatre, poor theatre, theatre on the wheels, street theatre and the like. It is theatre of the people, for the people and by the people. It has conscientization as its watchword and is carried out in the people's communities using their language and cultural indexes. Christopher Idah and Annas Ashaver of Theatre Arts Department, College of Education Kat sinaAla and Oju respectively, in separate interviews with the researcher in 2014 and 2015 affirmed that the two Departments make arrangements in rural communities and take NCE II students there in the first semester of every academic session for the exercise. In this way, the students are able to match theory with practice.

\section{Theatre Workshop Method}

Theatre workshop is a professionally performing arts teaching course for students in colleges of education in Nigeria. It strives at: teaching students and helping them to grow in the fields of drama, music and dance, creating an artistic atmosphere where creativity is inculcated in students, fostering and encouraging artistic excellence yearly. It of fers a variety of programmes for students to explore, imagine, enjoy, dream and most importantly leam. Also, it provides opportunities for emerging artists to get familiar with the form and content of theatre as well as acquire and develop skills of mounting theatrical productions. The emphasis is on teaching the arts of the theatre and helping students to expand their imagination and creativity as well as improving their coordination in a controlled environment. 
Theatre workshop is characterised by planning, rehearsal and presentation of the theatrical work or material to the audience at a given place by live performers who either use themselves or inanimate figures such as puppets as the media of present ation under a director. Every theatrical production is the product of a workshop experience where all the performers meet to acquire and improve on their skills by discussing their experiences and embarking on practical exercises in order to achieve an effective production. This is why Koppett Kate asserts that to be able to carry out an effective theatre workshop, "you need to have a background in theatre or a desire to perform ... a wish to enhance learning and infuse your environment with creativity, teamwork and effective communication" (xvii).

Theatre workshop method can therefore be described as a cardinal teaching method that supports students' creative development as artists, teachers and audience members by critically engaging them in the artistic process surrounding theatrical productions. Fach unit is designed with a list of objectives pertinent to the development of the students. It is a performance-based method with a multi-dimensional approach. The main objective is to encourage students to learn more about the world of theatre and they are expected to participate in at least three (3) theatre workshop 'practicals' before graduation.

\section{The Katsina-Ala and Oju Experiences of Theatre Workshop}

It must be established from the outset that the method of carrying out theatre workshop in the colleges of education under study is the same with a few differences. Both colleges mainly engage in dramatic activities in their workshop sessions with full length plays for the final year (NCE III) students. This is to ensure that all the elements of the theatre are found in the play and well coordinated to ascertain what the students have learned in the three years of their NCE training.

For instance, at College of Education, Oju, the departmental board of studies (DBS) of Theatre Arts Department allocates all courses meant to be taught for the semester to lecturers. In an interview with the immediate past Head of Department Annas Ashaver, she asserted that, "the DBS allocates all the courses for the semester to lecturers based on their areas of specialization. On the other hand, theatre workshop as a course is offered once in every session by all students of the department at each level. As a result, it is given special attention and its allocation to lecturers is not just based on specialization but experience and interest". In another interview with Christopher Idah the immediate past Examinations Of ficer of Theatre Arts Department, College of Education, Katsina-Ala, he asserted that, it is the Head of Department that allocates courses unlike what obtains at Oju and 
once theatre workshop as a course is allocated to a lecturer, he sets at to see to its execution. However, the criteria for allocating workshop courses are the same.

After the allocation of workshop courses, lecturers handling them at various levels are expected to meet with their students, introduce the courses and tell them what they are expected to do. Sequel to this is the selection of script for the workshop. This is done in line with the provisions of the department which Abuur Goowin, a lecturer at College of Education, Oju, noted that, "the department insists that plays selected for theatre workshop must be on contemporary issues, and address the problems of the college and host community". This is in consonance with Gowon Doki's assertion that "theatrical performance, for whatever function it is intended, is conceived within the ambience of human society and must reflect that society's beliefs, norms, and value system" (3). Selection of plays for workshop in Oju and KatsinaAla is done by the lecturers handling the courses and the same conditions apply.

After the play selection process, the lecturers cast the plays and start rehearsals. Depending on the availability of time, a lecturer might type-cast the play or decide otherwise where the actors will be worked on to play and look like the characters they are playing. It is pertinent to note that the process of casting a play is very crucial as it detemines the success of the production as captured by Jonathan Dorf when he noted that, "actors are in a sense the face of your production. No matter how good the script or the set or the lighting, without quality actors, the audience is unlikely to remember your show fondly. In fact, it has often been said that casting well is 90 percent of the work of production. That may not be entirely true but casting well is crucial to your success" (1) .

After the actors are cast for their roles, the rehearsal process cormences. It is worth noting that in every theatre workshop, the rehearsal stage is the most crucial and intensive one because, this is where all the arts of the theatre are taught practically on stage as students take up their roles either as actors/actresses, costumiers, make-up artists, lighting and scene designers, dancers, directors, and even playwrights. In separate interviews with Andera Tse, the Head of Department of Theatre Ants, College of Education, Katsina-Ala, and Joy Akuma, a lecturer in the Department of Theatre Ants Department, Oju, the rehearsal process is divided into five basic segments. The first segment is reading/play analysis rehearsal. This is followed by the blocking rehearsal. Third, is the general rehearsal in which actors rehearse with their scripts. The fourth stage is polishing rehearsal where the actors drop their scripts; polish their blockings, stage 
business and use required props. Lastly, is the dress and technical rehearsal in which the activities of the theatrical production team are harmonized and actors rehearse first with their costumes, sets and props and second, with lights. This is the point at which all the lecturers in the department are invited to see, critique and assess the students' performance. It is the peak of the exercise as students are advised on their flaws and strengths. This is to enable them open up channels for improvement in their subsequent productions.

In a focus group discussion (FGD) with selected students of the Department of Theatre Arts, College of Education, Oju, they admitted that, "lecturers who teach theatre workshop, most of the time, do not attend rehearsals and they (the students) are left to themselves." This as a matter of fact and most unfortunately too, is the disposition of some lecturers towards theatre workshop in many institutions. The outcome of this neglect is that, students are not exposed to the critical rudiments of the arts of the theatre as they should by their lecturers. The reverse is, however, the case in Kat sina-Ala where students in a focus group discussion (FGD) with the researcher, af firmed that lecturers handling workshop courses attend rehearsals and ensure that students are do not play truancy. This position is also af fimed by Joshua Jijingi who emerged the best graduating student of the Department and College of Ants in 2011.

Theatre workshop in Katsina-Ala and Oju Colleges of Education is multifaceted and aimed at achieving three different purposes: teaching students the art of play production with acting as the main pre-occupation, awareness creation in the immediate college community and beyond, and revenue generation as workshop productions are box office productions.

Problems of Teaching and Learning Theatre Arts in KatsinaAla and Oju Colleges of Education

The teaching and learning of theatre and drama at all levels of ecucation is beset by a number of challenges. On a general note, apart from its non-inclusion in the curriculum of primary and postprimary school systems, it has suffered relegation by management of tertiary institutions and universities thereby making teaching and leaming difficult for both staff and students of theatre arts studies. This explains why Joel Adedeji argues that "drama in education appears not to be a popular subject in the curriculum of the Nigerian secondary school and teacher training colleges and lack of manpower and materials for the subject are part of the problems" (77) .

Drawing on the foregoing, the fundamental problem of theatre teacher training in Katsina-Ala and Oju Colleges of Education is lack 
of manpower. The Department of Theatre Arts in the two colleges of education are grossly understaffed thereby making teaching and leaming extremely diffialt. According to Nolyer Teryila, the Dean of Arts, College of Education, Katsina-Ala, the Department of Theatre Arts had a total number of three hundred and ninety-four (394) students in the 2014/2015 session and the staff strength was just eleven (11) lectrrers. Its counterpart at the College of Education, Oju had a total number of three hundred of fifty-two (352) students in the 2014/2015 session with a staf strength of eleven (11) lecturers as affimed by Annas Ashaver. This short fall in st af is too dotrusive and no doubt has negatively affected the teaching and learning of theatre arts studies in these colleges.

Closely following the above is lack of infrastructure (equipment/ facilities). John Onah claims that the College of Education, Oju in Benue State is without a theatre structure and it relies on a building which could pass for a multipurpose hall. One, therefore, wonders how the department thrives with the teaching of theatre and hopes to graduate professionally sound artists; the teaching of a discipline that is practical-oriented in such an institution will definitely be imaginary or utopian in approach (87). On the other hand, the management of College of Education, Katsina-Ala, has recently built a befitting theatre for the department which is awaiting furnishing and formal handing over to the department. Onah further laments that "ironically, however, a startling state of the theatre discipline, and by extension, profession in Nigeria, is the pervasive circumstance of the dearth of relevant infrastructure: theatre structure and its technical accessories such as lighting facilities and other paraphernalia or apparatuses, required for its effective teaching and training" (81). This is the situation at Colleges of Education, Katsina-Ala and Oju as the departments are in dare need of lecture halls, equipment/facilities such as light equipment, costumes props and make-up kits for effective teaching and learning of theatre arts.

Lack of commitment on the part of some lecturers and students is another challenge. According to Olaniyan Modupe, there are many problems/challenges being faced by students and teachers in the teaching and learning of dramatic arts or theatre arts in Nigerian tertiary institutions. One of such problems is apathy. Many students are apathetical about studying dramatic arts because people believe, erroneously though, that drama/theatre is for the never-do-well people or vagabonds in the society (117). The problem of lack of commitment degenerates to apathy and is demonstrated in the manner in which some lecturers and students handle academic work. In fact, many students do not attend classes. Theatre workshop which is the melting 
point of the teaching and leaming of theatre arts is trivialized and seen as a mere ritual done to fulfil 'all righteousness' at the colleges of education under investigation. This has badly affected the teaching and leaming in these institutions.

Furthermore, inadequate funding and corruption is identified as a cardinal problem affecting the effective teaching and learning of theatre arts in Colleges of Education in Katsina-Ala and Oju. In this regard, Onah notes that "another problem that besets theatre education and training is corruption and the absence of rectitude in the issue of accreditation of theatre departments ..." (89). Because theatre workshop and other related practical courses are not sponsored in Katsina-Ala and Oju Colleges of Education, students contribute money to fund their productions and many a time, the course lecturers use such money to enrich themselves to the detriment of the students. On the other hand, the corruption that takes place during accreditation of the departments of theatre arts in these colleges of education is high given their poor staffing, infrastructure and equipment. This has seriously affected the mentality of students as well as teaching and learning activities.

The disruption of academic calendar and lack of time constitute another plank of the challenges to the teaching and learning of theatre arts. Because theatre arts is not a double major course, it has to be combined with another course as specified by the National Comission for Colleges of Education (NCCE), the regulatory body for Colleges of Education. As a result, it becomes difficult to carry out the numerous practical courses in the theatre curriculum thereby making learning defective. Besides, the numerous strikes faced by the colleges pose a big threat to teaching and leaming. A typical example of this is the industrial action embarked upon by all the unions in the colleges of education in 2014/2015 academic session, which lasted for almost nine (9) months. This is certainly not healthy for the teaching and leaming of all courses.

\section{Solutions}

The problems presented above which, are at present, affecting the teaching and learning of theatre arts in the colleges of education under study can be solved. However, there has to be a willingness to solve them by all the stakeholders involved. The problem of lack of manpower can be effectively solved by employing qualified persons who have read theatre arts even at the postgraduate level to teach in the colleges of education. The problem of infrastructure and equipment can be solved through planning and commitment. The Benue State government can strategically plan and commit resources to the 
provision of infrastructure and equipment in the colleges of education. The management of the colleges can commit internally generated revenue (IGR) to such ventures for enhanced teaching and learning of theatre arts.

On the problem of commitment of lecturers and students, the management of the colleges can improve on the welfare of lecturers by providing incentives in order to boast their morale and motivate them in doing their work ef fectively. One way of doing this is to give special allowances to lecturers who teach theatre workshop courses. There is the likelihood that once the students see the commitment of lecturers in ensuring that teaching and leaming is given priority, they will naturally fall in line or face the consequences of their indiscretion. On the issue of lack of funding and corruption, the colleges should fund at least theatre workshop courses. This will ameliorate the sufferings of the students who have to pay for their productions. On the other hand, the colleges can work towards meeting the requirements of the department for accreditation in order to avoid sharp practices to get theatre arts accredited. Heads of theatre department in the colleges of education should also be prudent in the management of resources assigned to them.

Furthermore, the National Commission for Colleges of Education (NCCE) and ministry of education should consider making theatre arts a double major course in colleges of education. This will expand the scope of the curriculum and give more room for the execution of practical courses. Lastly, the government of Benue State should respect agreements entered into with unions of tertiary institutions. This will go a long way in restoring the nomalcy in the system of education and also, forestall industrial actions which often paralyze academic activities in these institutions. In doing this, the academic calendar will be stabilized for effective teaching and leaming.

\section{Prospects of Effective Theatre Teacher Training}

It is easy to predict the future of theatre teacher training in Nigerian colleges of education in the light of the existing realities. It must be established that, theatre is both natural and indestructible. It is a pristine art that will continue to manifest itself under the most difficult conditions, while being regularly deployed for various ends, ranging from sheer entertainment to political or religious propaganda. One of the prospects of effective theatre teacher training at colleges of education is building a strong and viable manpower for primary and post-primary school systems. NCE holders of Theatre Arts are expected to teach drama, music and creative arts in the primary and post-primary schools. With good training, they stand a better chance of providing the needed manpower in the educational sector. 
Furthermore, an effective theatre teacher training can build a robust primary and post-primary school system. This is because, the quality of teachers that will be turned out into the system will revamp the system through dramatic and theatrical activities carried out in the schools. These could be in dramatic clubs, end of term or year celebrations, etc. By effectively packaging dramatic performances, cultural values and moral lessons can be taught thereby reinvigorating the primary and post-primary educational system. The theatre teacher training also has the capability of enhancing students' speech arts and self reliance. Theatre arts as a course has a mandatory speech component that can effectively take care of the needs of oral English, capable of reforming the deteriorating standard of oral communication in our schools. At present, the English language, at both oral and written levels, is in a dismal state, resulting in a dangerous trend of mutual unintelligibility. A conscientious programme of theatrical education can effectively reverse this ugly trend in our schools within a decade, thus improving communication at a wider social level. Effective theatre teacher training can enhance self reliance of theatre teachers who can be self employed given the diverse trainings they have received. Theatre teacher training should, therefore, be qualitative and resourceful given that it stands a good chance of facilitating a more viable primary and post-primary educational system in Nigeria.

\section{Conclusion}

Theatre arts plays a major role in reshaping the society and securing its future in a dynamic way. In the educational sector, theatre arts enhances learning and interaction among youths and school children as well as facilitate their self discovery and expression. This is why the teaching of theatre arts in colleges of education is imperative since the graduates are expected to take up the training of school children at pre-primary, primary and post primary school levels in arts and craft, as well as drama and music. This paper therefore submits that the department of theatre arts in colleges of education should liaise with management of their institutions to ensure that the problems of theatre teacher training are surmounted, especially those concerning manpower, motivation of lectures and provision of facilities/ equipment. 


\section{Works Cited}

Adedeji, Joel A. "Methodology of Drama in Education - Problems and Needs." National Workshop on Drama in Education. Ibadan: University of Ibadan, 1976.

Amanda, Swann. "The Value of Theatre Education." Web. 12 October 2015 http://www . cetoweb. org/ >.

Beck, A. et. al. Play Production in the High School. Skokie, USA: Nat. Textbook Coy, 1999.

Doki, Gowon A. Traditional Theatre in Perspective: Signs and Signification in Igbe, Girinya and

Kwagh-hir. Makurdi: Aboki Publishers, 2006.

Dorf, Jonathan. "Casting your Production." Web. 13 January 2015 $<\mathrm{ww}$ w.produceaplay.com/casting $>$.

Egwuda-Ugbeda, Felix. "Theatre Ethics as Panacea to Good Governance." Leadership and Good Governance in Modern Africa. Ed. O.O. Okpe and B.I .Due. Ibadan: House of Hists, 2015. 495-504.

Fafunwa, Babs A. History of Education in Nigeria. London: George Allen and Unwin, 1974.

Farrants, J.S. Principles and Practice of Education. London: Longman, 2004.

Jensen, Eric. Arts with the Brain in Mind. Alexandria, VA: A SCD Publishers, 2001.

Koppet, Kate. Training to Imagine. Virginia: Stylus Publishing ILC, 2001.

Olaniyan, Modupe E. "The Challenges and Prospects of Teaching and Learning Dramatic Art $\mathrm{s}$ in Tertiary Institutions in Nigeria." An International Multidisciplinary Journal 9.3 (2015) : 38- 44

Onah, John O. "Infrastructural Question and the Utopian Tendency of Theatre Training in Nigerian Higher Institutions." ANS U Journal of Theatre and Humanities 1.1 (2015): 80-91.

Peters, R. S. The Philosophy of Education. London: Oxford University Press, 2003.

W estwood, P. What Teachers Need to Know about Teaching Methods . Camberwell: ACER Press, 2008.

Oral Interviews

Abuul, Godwin. Lecturer, Department of Theatre Ants, College of Education (COE) Oju. 17 $7^{\text {th }}$ Nov, 2014.

Akuma, Joy. Lecturer, Department of Theatre Ants, COE Oju. 15 $5^{\text {th }}$ May, 2015.

Ashaver,Annas. Former Head, Department of Theatre Arts, COE Oju. $12^{\text {th }}$ September, 2015. 
Idah, Christopher. Examinations Of ficer, Department of Theatre Arts COE Kat sina-Ala. $23^{\text {rt }}$ Nov, 2014.

Jijingi, Joshua. at \$anding Student 2011, Department of Theatre Arts COE Katsina-Ala. 10 ${ }^{\text {th }}$ Oct, 2014.

Ndyer, Teryila. Dean, School of Ants and Social Science; Lecturer, Theatre Ants Department COE Katsina-Ala. 26 $6^{\text {th }}$ May, 2015.

Tse, Andera. Head, Theatre Arts Department, COE Katsina-Ala. 10 ${ }^{\text {th }}$ Oct, 2015. 